\title{
MASUKNYA ISLAM DI SPANYOL (Studi Naskah Sejarah Islam)
}

\author{
RUSNIATI \\ Universitas Muhammadiyah Makassar \\ rusniati@gmail.com
}

\begin{abstract}
Abstrak
Sejarah Islam di belahan bumi sejak dahulu menjadi bukti Islam pernah berjaya di belahan bumi ini. Salah satunya di Spanyol. Spanyol adalah sebuah Negara yang pernah ditaklukkan oleh Islam untuk mengembangkan agama Islam di negeri tersebut.Ketika Islam masuk ke negeri Spanyol, negeri ini banyak mengalami peradaban yang pesat baik dari kebudayaan maupun pendidikan Islam, karena Spanyol didukung negerinya yang subur dengan penghasilan ekonomi yang cukup tinggi sehingga menghasilkan para pemikir hebat.Spanyol mengalami perkembangan pesat dan kebudayaan dan pendidikan Islam yang dimulai dengan mempelajari ilmu agama dan sastra, kemudian meningkat dengan mempelajari ilmu-ilmu akal. Sejarah kejayaan Islam di Spanyol perlu dikaji awal kemunculannya. Oleh karena itu, kajian ini mendalami sejarah masuknya Islam di Spanyol. Penelitian ini merupakan penelitian kualitatif yang mendeskripsikan semua data yang ditemukan melalui pendekatan kepustakaan. Pendekaan kepustakaan digunakan untuk menghimpun berbagai literatur dan dokumendokumen terdahulu terkait objek penelitian. Penelitian ini tidak menetapkan suatu lokasi sebagai tempat penelitian karena kajiannya cenderung pada naskah teks. Pada tahap ini dilakukan kegiatan yang berupa mengolah data diperoleh dari dokumen, kemudian akan disusun kedalam sebuah penelitian. Hasil analisis tersebut dituangkan dalam bentuk laporan penelitian secera deskriptif. Hasil kajian menunjukkan bahwa Asal usul masuknya Islam di Spanyol tidak lepas dari keberhasilan Thariq ibn Ziyad mengalahkan raja Roderick, sehingga kemenangan ini menjadi modal utama bagi Thariq ibn Ziyad dan pasukannya untuk menaklukkan kota-kota penting yang ada di Spanyol.
\end{abstract}

Kata kunci: Islam, Spanyol, Cordova, Sejarah Islam.

\section{PENDAHULUAN}

Spanyol adalah sebuah Negara yang pernah ditaklukkan oleh Islam untuk mengembangkan agama Islam di negeri tersebut.Ketika Islam masuk ke negeri Spanyol, negeri ini banyak mengalami peradaban yang pesat baik dari kebudayaan maupun pendidikan Islam, karena Spanyol didukung negerinya yang subur dengan penghasilan ekonomi yang cukup tinggi sehingga menghasilkan para pemikir hebat.Spanyol mengalami perkembangan pesat dan kebudayaan dan pendidikan Islam yang dimulai dengan mempelajari ilmu agama dan sastra, kemudian meningkat dengan mempelajari ilmu-ilmu akal.Dalam waktu relatif singkat Cardova 
dapat menyaingi Baghdad dalam bidang ilmu pengetahuan dan kesastraan. ${ }^{1}$ Karena itu kehadiran Islam di Spanyol banyak menarik perhatian para sejarawan.

Spanyol merupakan tempat paling strategis bagi Eropa pada waktu itu untuk menggali peradaban Islam yang tak tertandingi baik dalam bentuk hubungan politik, sosial, maupun perekonomian dan peradaban antar agama.Orang-orang Eropa menjadi saksi sejarah bahwa Spanyol dibawah panji Islam jauh meninggalkan negara-negara tetangganya di Eropa terutama di bidang pemikiran, sains, dan peradaban. ${ }^{2}$

Ibukota Spanyol Islam yang dalam bahasa Arab disebut al-Andalus (dari kata Vandals).Dulunya bernama Iberia.Ketika Romawi berkuasa (abad ke 2) mereka menamainya "Asbania" (pantai Marmot). Spanyol adalah sebuah propinsi yang beribukota Cordova pada masa pemerintahan Bani Umayyah di Barat (1756-1031 M), luas wilayahnya $13.727 \mathrm{~km}^{2}$ dan jumlah penduduknya sekitar 782.999 jiwa. ${ }^{3}$ Islam pada masa ini telah berubah menjadi dokumen sejarah tersendiri bagi perjalanan masa-masa keemasan Islam yang patut menjadi perhatian bagi generasi sekarang.

Menurut Philip K. Hitty bahwa umat Islam pada masa 711-1490 M pernah mencatat satusatunya lembaran tercemerlang di dalam sejarah pemikiran orang Eropa dan pada abad pertengahan, the golden age (masa keemasan). Akan tetapi, meskipun pemerintah tersebut pernah berjaya dan bergensi di Eropa, namun harus diakui pula bahwa pemerintahan tersebut juga mengalami kemunduran, bermula ketika meninggalnya al Hakam II dan akhirnya secara berlahan-lahan daulat tersebut menemui kehancurannya. Berdasarkan uraian tersebut, penulis akan menguraian sejarah masuknya Islam di Spanyol.

\section{METODE PENELITIAN}

Penelitian ini merupakan penelitian kualitatif yang mendeskripsikan semua data yang ditemukan melalui pendekatan kepustakaan. Pendekaan kepustakaan digunakan untuk menghimpun berbagai literatur dan dokumen-dokumen terdahulu terkait objek penelitian. Penelitian ini tidak menetapkan suatu lokasi sebagai tempat penelitian karena kajiannya cenderung pada naskah teks. Pada tahap ini dilakukan kegiatan yang berupa mengolah data

\footnotetext{
${ }^{1}$ Badri Yatim, Sejarah Peradaban Islam (Cet. V; Jakarta: PT. RajaGrafindo Persada, 1997), h. 87.

${ }^{2}$ Philip K. Hitti, History of The Arabs (London: Macmilan Press LTD,1974), h. 526-530.

${ }^{3}$ Hasan Muarif Anbari, Ensiklopedia Islam, (Jakarta: PT. Ikhtiar Baru Van Hoeve, 1994), h. 275.
} 
diperoleh dari dokumen, kemudian akan disusun ke dalam sebuah penelitian. Hasil analisis tersebut dituangkan dalam bentuk laporan penelitian secera deskriptif.

\section{HASIL DAN PEMBAHASAN}

\section{Asal-Usul Masuknya Islam Ke Spanyol}

Islam pertama kali masuk ke Spanyol pada tahun $711 \mathrm{M}$ melalui jalur Afrika Utara. Spanyol sebelum kedatangan Islam dikenal dengan nama Iberia/ Asbania, kemudian disebut Andalusia, ketika negeri subur itu dikuasai bangsa Vandal. Dari perkataan Vandal inilah orang Arab menyebutnya Andalusia. ${ }^{4}$ Sebelum penaklukan Spanyol, umat Islam telah menguasai Afrika Utara dan menjadikannya sebagai salah satu provinsi dari dinasti Bani Umayah.Penguasaan sepenuhnya atas Afrika Utara itu terjadi di zaman Khalifah Abdul Malik (685-705 M). Khalifah Abd al-Malik mengangkat Hasan Ibn Nu'man al-Ghassani menjadi gubernur di daerah itu.Pada masa Khalifah al-Walid, Hasan ibn Nu'man sudah digantikan oleh Musa Ibn Nushair.Di zaman al-Walid itu, Musa ibn Nushair memperluas wilayah kekuasaannya dengan menduduki Aljazair dan Maroko. Selain itu, ia juga menyempurnakan penaklukan ke daerah-daerah bekas kekuasaan bangsa Barbar di pegunungan-pegunungan sehingga mereka menyatakan setia dan berjanji tidak akan membuat kekacauan-kekacauan seperti yang pernah mereka lakukan sebelumnya. ${ }^{5}$

Penaklukan atas wilayah Afrika Utara itu dari pertama kali dikalahkan sampai menjadi salah satu provinsi dari Khalifah Bani Umayah memakan waktu selama 53 tahun, yaitu mulai tahun $30 \mathrm{H}$ (masa pemerintahan Muawiyah ibn Abi Sufyan) sampai tahun 83 H (masa al-Walid). Sebelum dikalahkan dan kemudian dikuasai Islam, dikawasan ini terdapat kantung-kantung yang menjadi basis kekuasaan kerajaan Romawi, yaitu kerajaan Gotik. Dalam proses penaklukan Spanyol terdapat tiga pahlawan Islam yang dapat dikatakan paling berjasa memimpin satuansatuan pasukan ke sana. Mereka adalah Tharif ibn Malik, Tharik ibn Ziyad, dan Musa ibn Nushair.Tharif dapat disebut sebagai perintis dan penyelidik.Ia menyeberangi selat yang berada diantara Maroko dan benua Eropa itu dengan satu pasukan perang lima ratus orang di antaranya adalah tentara berkuda, mereka menaiki empat buah kapal yang disediakan oleh Julian. Ia menang dan kembali ke Afrika Utara membawa harta rampasan yang tidak sedikit jumlahnya.

\footnotetext{
${ }^{4}$ Perpustakaan Nasional : Katalog Dalam Terbitan(KDT), Ensiklopedi Mini Sejarah dan Kebudayaan Islam (Logos Wacana Ilmu, Jakarta 1996), h.

${ }^{5}$ Samsul Munir Amin, Sejarah Peradaban Islam (Cet.II; Jakarta: Amzah, 2010), h.162.
} 
Didorong oleh keberhasilan Tharif dan kemelut yang terjadi dalam tubuh kerajaan Visigothic yang berkuasa di Spanyol pada saat itu, serta dorongan yang besar untuk memperoleh harta rampasan perang, Musa ibn Nushair pada tahun 711 M mengirim pasukan ke Spanyol sebanyak 7000 orang di bawah pimpinan Thariq ibn Ziyad. ${ }^{6}$

Thariq ibn Ziyad lebih banyak dikenal sebagai penaklukan Spanyol karena pasukannya lebih besar dan hasilnya lebih nyata. Pasukannya terdiri dari sebagian besar suku Barbar yang didukung oleh Musa ibn Nushair dan sebagian lagi orang Arab yang dikirim Khalifah alWalid.Pasukan itu kemudian menyeberangi selat di bawah pimpinan Thariq ibn Ziyad. Sebuah gunung tempat pertama kali Thariq dan pasukannya mendarat dan menyiapkan pasukannya, dikenal dengan nama Gibraltar (Jabal Thariq). Dalam pertempuran di Bakkah, Raja Roderick dapat dikalahkan. Dari situ seperti Cordova, Granada dan Toledo (Ibu kota kerajaan Goth saat itu). ${ }^{7}$ Kebudayaan Islam memasuki Eropa melalui beberapa jalan, antara lain melewati Andalusia.Ini karena kaum muslimin telah menetap di negeri itu sekitar abad 8 abad lamanya.Pada masa itu kebudayaan Islam di negeri itu mencapai puncak perkembangannya.Kebudayaan Islam di Andalusia mengalami perkembangan yang pesat diberbagai pusatnya, misalnya Cordova, Sevilla, Granada, dan Toledo. ${ }^{8}$

Kemenangan pertama yang dicapai oleh Thariq ibn Ziyad membuka jalan untuk penaklukan wilayah yang lebih luas lagi. Selanjutnya, keduanya berhasil menguasai seluruh kota penting di Spanyol, termasuk bagian utaranya mulai dari Saragosa sampai Navarre. Gelombang perluasan wilayah berikutnya muncul pada masa pemerintahan Khalifah Umar ibn Abdil Aziz tahun 99 H/717 M, dengan sasarannya menguasai daerah sekitar pegunungan Pyrenia dan Prancis Selatan. Gelombang kedua terbesar dari penyerbuan kaum muslimin yang geraknya dimulai pada permulaan abad ke-8 M ini, telah menjangkau seluruh Spanyol dan melebar jauh ke Prancis Tengah dan bagian-bagian penting dari Italia. Adapun kemenangan - kemenangan yang dicapai umat Islam nampak begitu mudah, hal itu dapat dipisahkan dari adanya faktor eksternal dan internal, yaitu :

\footnotetext{
${ }^{6}$ Philip K. Hitti, History of The Arabs, h. 628.

${ }^{7}$ Badri Yatim, Sejarah Peradaban Islam, h. 89.

${ }^{8}$ Abdul Mun'im Majid, Sejarah Kebudayaan Islam (t.t: Pustaka,1997), h.182.
} 


\section{a. Faktor eksternal,}

Adapun yang dimaksud dengan faktor eksternal ini adalah suatu keadaan yang terdapat dalam negeri Andalusia itu sendiri.Dimana saat itu kondisi sosial, politik dan ekonomi negeri ini dalam keadaan menyedihkan. ${ }^{9}$ Secara politik wilayah Andalusia terkoyakkoyak dan terbagi-bagi kedalam beberapa negeri kecil. Ditambah penguasa yaitu aliran Gothic bersikaf tidak toleran terhadap aliran agama penguasa yaitu aliran Monofisit, apalagi terhadap penganut agama lain. Sementara penganut agama terbesar penduduk Andalusia adalah agama yahudi, mereka dipaksa dibaptis menurut agama Kristen.Rakyat dibagi kepada kelas-kelas sehingga keadaannya diliputi oleh kemelaratan, ketertindasan, ketiadaan persamaan hak.

b. Faktor internal

Adapun yang dimaksud dengan faktor internal adalah suatu kondisi yang terdapat dalam tubuh penguasa Islam, termasuk tokoh-tokoh pejuang dan para prajurit Islam yang terlibat dalam penaklukkan wilayah Andalusia pada khususnya.Para pemimpin adalah tokohtokoh yang kuat, tentaranya kompak, bersatu dan penuh percaya diri.Yang tak kalah pentingnya adalah ajaran Islam yang ditinjukkan para tentara Islam, yaitu toleransi, persaudaraan yang terdapat dalam pribadi kaum muslimin itu menyebabkan Andalusia menyambut kehadiran Islam disana. ${ }^{10}$

Dalam kurung waktu 7,5 abad Islam Spanyol telah berkembang dengan pesatnya yang pada gilirannya mampu membawa dampak yang sangat besar bagi dunia keilmuan dan pengetahuan yang terjadi di Eropa pada Umumnya. Selama Islam berkuasa di Spanyol, banyak terdapat penguasa negeri yang memerintah, di antaranya adalah :

1. Amir- Amir Bani Umayyah,

2. Khalifah-khalifah Bani Umayyah,

3. Daulah Ziriyah di Granada,

4. Daulah Bani Hamud di Malaga,

5. Daulah Bani Daniyah,

6. Daulahh Bani Najib dan Bani Hud di Saragosa,

${ }^{9}$ Badri Yatim, Sejarah Peradaban Islam, h. 91.

${ }^{10} \mathrm{http}: / /$ makalah-for-you.blogspot.co.id/2014/07/makalah-sejarah-peradaban-islam-di.html, di akses pada tanggal 23/06/16. 
7. Daulah Aniriyah di Valensia,

8. Daulah Bani Ubbad di Sevilla,

9. Daulah Jahuriyah di Cordova,

10. Daulah Bani Zin-Nun di Toledo, dan

11. Daulah Bani Ahmar di Spanyol. ${ }^{11}$

Sejak pertama kali menginjakkan kaki di tanah Spanyol hingga jatuhnya kerajaan Islam terakhir di sana, Islam memainkan peran yang sangat besar. Sejarah panjang yang dilalui umat Islam di Spanyol itu dapat dibagi menjadi enam periode, yaitu:

\section{Periode Pertama (711-755 M)}

Pada Periode ini, Spanyol berada di bawah pemerintahan para wali yang diangkat oleh khalifah Bani Umayyah yang berpusat di Damaskus.Pada periode ini stabititas politik negeri Spanyol belum terkendali akibat gangguan keamanan di beberapa wilayah, karena pada masa ini adalah masa peletakan dasar, asas dan invasi Islam di Spanyol.Hal ini ditandai dengan adanya gangguan dari berbagai pihak yang tidak senang kepada Islam.Sentralisasi kekuasaan masih di bawah Daulat Umayyah di Damaskus. ${ }^{12}$

Sisa-sisa musuh Islam di Spanyol yang bertempat tinggal di pegunungan yang tidak tunduk pada pemerintahan Islam juga terus mengganggu stabititas politik dan keamanan.Karena seringnya terjadi konflik maka dalam periode ini Islam Spanyol belum melakukan pembangunan di bidang peradaban dan kebudayaan.Periode ini berakhir dengan datangnya Abd Rahman alDakhil ke Spanyol tahun 755 M. ${ }^{13}$

\section{Periode Kedua (755-912 M)}

Pada masa ini Spanyol berada di bawah pemerintahan seorang yang bergelar amir (panglima atau gubernur), tetapi tidak tunduk kepada pusat pemerintahan Islam, yang ketika itu dipegang oleh Khalifah Abbasiyah di Bagdad. Amir pertama adalah Abdurrahman I yang memasuki Spanyol tahun 138 H/755 M dan diberi gelar al-Dakhi>l (yang masuk ke Spanyol). ${ }^{14}$ Dan adalah keturunan Bani Umayyah yang berhasil lolos dari kerajaan Bani Abbas,

${ }^{11}$ Abdullah Salim, Sumbangan Andalusia Kepada Dunia Barat (Semarang: Unisullah Press, 1999), h. 8.

${ }^{12}$ A. Mukti Ali, Sejarah Islam Pramodern, (Jakarta: PT. RajaGrafindo Persada, 1995), h. 319.

${ }^{13}$ Hamka, Sejarah Umat Islam, (Jakarta: Penerbit Bulan Bintang, 1981), h. 134.

${ }^{14}$ Yusran Asmuni, Dirasah Islamiyah III, Pengantar Studi Sejarah kebudayaan Islam dan Pemikiran, (Jakarta: PT. RajaGrafindo Persada, 1996), h. 14-15. 
ketika Bani Abbas berhasil menaklukkan Bani Umayyah di Damaskus. Selanjutnya, ia berhasil mendirikan Dinasti Bani Umayyah di Spanyol. Adapun urutan keamiran Bani Umayyah di Spanyol sebagai berikut: ${ }^{15}$

\section{a. Abd al-Rahman al-Dakhil (755-788 M)}

Abd al-Rahman al-Dakhil adalah amir pertama, dikenal dengan nama Abdul Rahman I, cucu dari Hisyam Khalifah Umayyah, yang berhasil lolos dari kejaran Bani Abbas ketika berhasil menaklukkan Bani Umayyah di Damaskus. Selanjutnya dia mendirikan Dinasti Bani Umayyah di Spanyol.Dengan dukungan bangsa Barbar dari Afrika Utara dan Syiria pada masa rezim Umayyah di Spanyol. Rezim baru ini mengikuti pola-pola pemerintahan lokal, dan membentuk angkatan bersenjata terdiri dari para klien dari Pyreness.

Abdurrahman al-Dakhil diangkat sebagai Gubernur Cordova pada bulan Desember $755 \mathrm{M}$ dan bulan Mei berikutnya Abdurrahman al-Dakhil membangun tempat tinggal di kota itu serta mengangkat dirinya sebagai amir. Abdurrahman al-Dakhil memasuki Spanyol pada tahun 755 M. dan diberi gelar al-Dakhil (yang masuk ke Spanyol). Abdurrahman al-Dakhil memperindah kotakota, membangun benteng-benteng yang kokoh dan istana, serta meletakkan batu yang pertama untuk membangun mesjid yang terbesar nantinya di belahan Dunia Islam maupun, yang dilakukan dua tahun sebelum wafatnya tahun $789 \mathrm{M}$.

\section{b. Hisyam Ibnu Abdurrahman (788-796 M)}

Adalah anak dari Abdurrahman al-Dakhil yang ditunjuk untuk menggantinya.Dikenal sebagai Hisyam I yaitu amir kedua.Merupakan pemimpin yang takwa dan wara'.Pada masa ini tersebar madzhab Maliki di Spanyol yang berasal dari Imam Malik ibn Anas yang berpusat di Madinah.Madzhab Maliki disebarkan oleh Ziyad ibn Abdurrahman, seorang ulama yang belajar ke Madinah untuk mempelajari Madzhab Maliki secara langsung dari Imam Malik. ${ }^{16}$

Pada masa ini Hisyam I menghadapi pemberontakan yang dilancarkan oleh saudaranya di Toledo yakni Abdullah dan Sulaiman.Hisyam mengarahkan perhatiannya ke wilayah Utara.Umat Kristen yang melancarkan gangguan keamanan ditindasnya sekaligus berhasil mengalahkan kekuatan Perancis.Kota Norebonne ditaklukkannya, sementara suku Gakicia mengajukan perundingan perdamaian. ${ }^{17}$

\footnotetext{
${ }^{15}$ Badri Yatim, Sejarah Peradaban Islam, h. 95.

${ }^{16}$ M. Mansyur Amin, Sejarah Peradaban Islam(Bandung: Indonesia Spirit Foundation, 2004), h. 188.

${ }^{17}$ Joesoef Sou'yb, Sejarah Daulat Umayyah di Cordova(Jakarta: Penerbit Bulan Bintang, th), h. 44.
} 
Hisyam merupakan penguasa yang adil dan murah hati khususnya terhadap rakyat lemah dan miskin.Ia membangun jembatan Cordova dan merampungkan pembangunan mesjid dan gereja yang dibangun oleh ayahnya. Ulama Spanyol menduduki tempat yang tinggi di kerajaan dan memberi nasehat kepada penguasa. ${ }^{18}$ Hisyam ibnu Abdurrahman memerintah selama 8 tahun dan wafat pada tahun 796 M. kendali pemerintahan diteruskan oleh anaknya Hakam ibn Hisyam. $^{19}$

Pada masa ini umat Islam di Spanyol mulai memperoleh kemajuan-kemajuan, baik dalam bidang politik, peradaban serta pendidikan.Abdurrahman mendirikan mesjid Cardova dan sekolah-sekolah di kota-kota besar di Spanyol. Kemudian penerus-penerusnya yang lain seperti Hisyam dikenal berjasa dalam menegakkan hukum Islam, dan Hakam dikenal sebagai pembaharu dalam bidang kemiliteran, sedangkan Abdurrahman al-Ausath dikenal sebagai penguasa yang cinta ilmu. Pada masa Abdurrahman al-Ausath ini pemikiran filsafat mulai masuk, maka ia mengundang para ahli dari dunia Islam lainnya untuk datang ke Spanyol sehingga kegiatan ilmu pengetahuan di Spanyol mulai semarak. ${ }^{20}$

\section{Periode Ketiga (912-916 M)}

Periode ini berlangsung mulai dari pemerintahan Abdurrahman III, yang bergelar "AnNasir" sampai munculnya mulu>k al-t\}awa>if (raja-raja kelompok). Pada periode ini Spanyol diperintah oleh penguasa dengan "Khalifah".Pada periode ini juga umat Islam di Spanyol mencapai puncak kemajuan dan kejayaan menyaingi Daulat Abbasiyah di Bagdad.Abdurrahman an-Nasir mendirikan Universitas Cordova.Perpustakaannya memiliki koleksi ratusan ribu buku.Hakam II juga seorang kolektor buku dan pendiri perpustakaan. ${ }^{21}$

\section{Periode Keempat (1013-1086 M)}

Pada periode ini Spanyol terpecah menjadi lebih dari tiga puluh negara kecil di bawah pimpinan raja-raja golongan atau Al-mulu>kal-T\}awa>if, yang berpusat di suatu kota seperti Siville, Toledo dan sebagainya. Yang terbesar diantaranya adalah Abbadiyah di Seville, Cordova, Toledo, dan sebagainya.Pada priode ini umat Islam Spanyol kembali memasuki masa pertikaian intern.Ironisnya, kalau terjadi perang saudara, ada di antara pihak-pihak yang bertikai itu yang

\footnotetext{
${ }^{18}$ M. Mansyur Amin, Sejarah Peradaban Islam,h. 188.

${ }^{19}$ M. Mansyur Amin, Sejarah Peradaban Islam, h. 118.

${ }^{20}$ Badri Yatim, Sejarah Peradaban Islam, h. 95.

${ }^{21}$ Badri Yatim, Sejarah Peradaban Islam, h. 96-97.
} 
meminta bantuan kepada raja-raja Kristen.Melihat kelemahan dan kekacauan yang menimpa keadaan politik Islam itu, untuk pertama kalinya, orang-orang Kristen pada periode ini mulai mengambil inisiatif penyerangan. Meskipun, kehidupan politik tidak stabil, namun, kehidupan intelektual terus berkembang pada periode ini, istana-istana mendorong para sarjana dan sastrawan untuk mendapatkan perlindungan dari satu istana keistana lain. ${ }^{22}$

\section{Periode Kelima (1086-1248 M)}

Pada periode ini, Spanyol Islam meskipun masih terpecah dalam beberapa negara, tetapi terdapat satu kekuatan yang dominan, yaitu kekuasaan dinasti Murabithun (1086-1143 M) dan dinasti Muwahhidun (1146-1235 M).Dinasti Murabithun pada mulanaya adalah sebuah gerakan agama yang didirikan oleh Yusuf ibn Tasyfin di Afrika Utara. Pada tahun $1062 \mathrm{M}$ ia berhasil mendirikan sebuah kerajaan berpusat di Marakesy. Ia masuk ke Spanyol atas "Undangan" penguasa-penguasa Islam di sana yang tengah memikul beban berat perjuangan mempertahankan negeri-negerinya dari serangan-serangan orang-orang Kristen. Ia dan tentaranya memasuki Spanyol pada tahun $1086 \mathrm{M}$ dan berhasil mengalahkan pasukan Castilia. Karena perpecahan di kalangan raja-raja Muslim, Yusuf melangkah lebih jauh untuk menguasai Spanyol dan ia berhasil untuk itu. Akan tetapi, penguasa-penguasa sesudah ibn Tasyfin adalah raja-raja yang lemah. Pada tahun 1143 M, kekuasaan dinasti ini berakhir, baik di Afrika Utara maupun dinasti Murabithun, Saragossa jatuh ke tangan Kristen, tepatnya tahun 1118 M.

Di Spanyol sendiri, sepeninggal dinasti ini, pada mulanya kembali dinasti-dinasti kecil, tapi hanya berlangsung tiga tahun.Pada tahun $1146 \mathrm{M}$ penguasa dinasti Muwahhidun yang berpusat di Afrika Utara merebut daerah ini.Muwahhidun didirikan oleh Muhammad ibn Tumart (w. 1128).Dinasti ini datang ke Spanyol di bawah pimpinan Abd Al-Mun'im. Antara tahun 1114 dan 1154 M, kota-kota Muslim penting, Cordova, Almeria, dan Granada, jatuh kebawah kekuasaannya. Untuk jangka beberapa decade, dinasti ini mengalami banyak kemajuan.Kekuatan-kekuatan Kristen dapat dipukul mundur.Akan tetapi, tidak lama setelah itu, Muwahhidun mengalami keambrukan.Pada tahun 1212 M, tentara Kristen memperoleh kemenangan besar di Las Navas de Tolesa.Kekalahan-kekalahan yang dialami Muwahhidun menyebabkan penguasanya memilih untuk meninggalkan Spanyol dan kembali ke Afrika Utara tahun 1235 M. Keadaan Spanyol kembali runyam, berada di bawah penguasa-penguasa

\footnotetext{
${ }^{22}$ Badri Yatim, Sejarah Peradaban Islam h. 97-98.

${ }^{23}$ M. Mansyur Amin, Sejarah Peradaban Islam, h. 121-122.
} 
kecil.Dalam kondisi demikian, umat Islam tidak mampu bertahan dari serangan-serangan Kristen yang semakin besar.Tahun 1238 M Cordova jatuh ke tangan penguasa Kristen dan Seville jatuh tahun 1248 M. Seluruh Spanyol kecuali Granada lepas dari kekuasaan Islam. ${ }^{24}$

\section{Periode Keenam (1248-1492 M)}

Pada periode ini, Islam hanya berkuasa di daerah Granada, di bawah dinasti Bani Ahmar (1232-1492).Peradaban kembali mengalami kemajuan seperti di zaman Abdurrahman AnNasir.Akan tetapi, secara politik, dinasti ini hanya berkuasa di wilayah yang kecil.Kekuasaan Islam yang merupakan pertahanan terakhir di Spanyol ini berakhir, karena perselisihan orangorang istana dalam memperebutkan kekuasaan. Abu Abdullah Muhammad merasa tidak senang kepada ayahnya, karena menunjuk anaknya yang lain sebagai penggantinya menjadi raja. Dia memberontak dan berusaha merampas kekuasaan.Dalam pemberontakan itu, ayahnya terbunuh dan digantikan oleh Muhammad ibn Sa'ad.Abu Abdullah kemudian meminta bantuan kepada Ferdenand dan Isabella untuk untuk menjatuhkannya.Dua penguasa Kristen ini dapat mengalahkan penguasa yang sah dan Abu Abdullah naik tahta.

Tentu saja, Ferdinand dan Isabella yang mempersatukan dua kerajaan besar Kristen melalui perkawinan itu tidak cukup merasa puas.Keduanya ingin merebut kekuasaan terakhir umat Islam di Spanyol.Abu Abdullah tidak kuasa menahan serangan-serangan orang Kristen tersebut dan pada akhirnya mengaku kalah.Ia menyerahkan kekuasaan kepada Ferdinand dan Isabella, kemudian, hijrah ke Afrika Utara. Dengan demikian berakhirlah kekuasaan Islam di Spanyol tahun 1492 M. Umat Islam setelah itu dihadapkan kepada dua pilihan, masuk Kristen atau pergi meninggal Spanyol.Pada tahun 1609 M, boleh dikatakan tidak ada lagi umat Islam di daerah ini. $^{25}$

\section{PENUTUP}

Dari Uraian tersebut di atas maka dapat disimpulkan sebagai berikut:

1. Asal usul masuknya Islam di Spanyol tidak lepas dari keberhasilan Thariq ibn Ziyad mengalahkan raja Roderick, sehingga kemenangan ini menjadi modal utama bagi Thariq ibn Ziyad dan pasukannya untuk menaklukkan kota-kota penting yang ada di Spanyol.

\footnotetext{
${ }^{24}$ Badri Yatim, Sejarah Peradaban Islam, h. 98-99.

${ }^{25}$ Badri Yatim, Sejarah Peradaban Islam, h. 99-100.
} 
2. Spanyol merupakan tempat yang paling utama bagi Eropa dalam penyerapan ilmu pengetahuan yang dikembangkan umat Islam di sana serta peradabannya, baik dalam hubungan politik, sosial, maupun ekonomi dam peradaban antar Negara. Adapun kemajuan intelektual yang di dalamnya terdapat ilmu filsafat, sains, fikih, musik dan kesenian, begitu juga dengan bahasa dan sastra, dan kemegahan pembangunan fisik. Adapun sebab kemunduran Islam di Spanyol terbagi menjadi dua yaitu:

1. Faktor internal
a. Sistem peralihan kekuasaan atau kekhalifaan yang kurang jelas
b. Munculnya Mulu>k Al-T\}awa>if (kerajaan-kerajaan kecil)
c. Fanatisme Kesukuan
d. Kesulitan Ekonomi

2. Faktor Eksternal
a. Karena Wilayah Spanyol Terpencil
b. Konflik Antara Islam dengan Kristen.

\section{DAFTAR PUSTAKA}

Ali, A. Mukti. (1995). Sejarah Islam Pramodern, Jakarta: PT. RajaGrafindo Persada.

Amin, M. Mansyur. (2004). Sejarah Peradaban Islam, Bandung: Indonesia Spirit Foundation.

Anbari, Hasan Muarif. (1994). Ensiklopedia Islam. Jakarta: PT. Ikhtiar Baru Van Hoeve.

Asmuni,Zainuddin Asmuni. (2000). Muslim Education Thought in the Middle Age, Terj.Abuddin Nata, Bandung: Angkasa.

Asmuni,Yusran. (1996). Dirasah Islamiyah III, Pengantar Studi Sejarah kebudayaan Islam dan Pemikiran. Jakarta: PT. RajaGrafindo Persada.

Fakhri, Majid. (1986). Sejarah Filsafat Islam, Jakarta: Pustaka Jaya.

H. Hart, Michael. (1991). The 100 a Ranking of Most Influencing Power in History, Terj. Makbuk Djunaedi. Seratus Tokoh yang Paling Berpengaruh dalam Sejarah. Jakarta: Pustaka Jaya.

Hamka. (1981). Sejarah Umat Islam. Jakarta: Penerbit Bulan Bintang.

Hilman ,Jahdan. (1989). Sejarah dan Kebudayaan Islam.Yogyakarta: Kota Kembang, 1989.

Hittin, Philip K. (2008). History of The Arabs, Diterjemahkan oleh R. Cecep Lukman Yasin, Jakarta: PT Serambi Ilmu Semesta.

Lewis, Bernard. (1988). The Arabs in History, Terj.Said Jamhensi, Bangsa Arab dalam Lintasan Sejarah. Jakarta: Pedoman Ilmu Jaya.

Nasution, Harun. (1985). Islam Ditinjau dari Berbagai Aspek. Jakarta: UI Press. 
Poeradisastra,S.I. (1986). Sumbangan Islam kepada Ilmu dan Peradaban Modern. Jakarta: P3M. Sou'yb, Joesoef. Sejarah Daulat Umayyah di Cordova, Jakarta, Penerbit Bulan Bintang, tth.

Sunanto, Musyrifah. (2007). Sejarah Islam Klasik: Perkembangan Ilmu Pengetahuan Islam. Jakarta: Kencana Prenada Media Group.

Syah Nasution, Hasyim. (1999). Filsafat Islam. Jakarta: Gaya Media Pratama.

Syalabi, Ahmad. (1983). Sejarah Kebudayaan Islam, Jakarta: Pustaka Al-Husna, 1983.

Tim Penulis IAIN Syarif Hidayatullah. (1992). Ensiklopedi Islam Indonesia . Jakarta: Djambatan.

Wahyudi, Yudian dkk. (1992). Analisa Runtuhnya Daulah-daulah Islamiyah. Solo: Pustaka Manthiq.

Yahaya, Mahayudin. (1990). Islam di Spanyol dan Sicily.Kuala Lumpur: Dewan Bahasa dan Pustaka Kementrian Pendidikan Malaysia.

Yatim, Badri. (2004). Sejarah Peradaban Islam, Jakarta: PT RajaGrafindo. 